Cumhuriyet International Journal of Education-CIJE

e-ISSN: 2147-1606

Vol 5 (1), 2016, $71-84$

\title{
Analyzing Activity Plans' Parental Involvement Section in Early Childhood Education
}

\section{Zeynep KURTULMUŞ}

\author{
Summary
}

\section{INTRODUCTION}

It has been suggested that parental involvement enhances children's academic achievement, language development and social development. Having parent involvement in their children's education is an interaction and cooperation process between parent and school (McDonald, Culp et all., 2000; Ekinci-Vural, 2006). Turkish early childhood program offers teachers affective methods to support parental involvement process. The parental involvement section in activity plans is a part of parent involvement methods. It is expected that parental involvement would be effective. For this reason the purpose of this study was to analyze activity plan's parental involvement section.

\section{METHOD}

This study is a descriptive study using document analyses technique. Document analyses technique is a procedure of systematic investigation of documents (Karasar, 2011). Activity plans were collected from randomly selected preschools from the central district of Ankara. These activity plans were Turkish, reading and writing readiness, drama, mathematics, play and movement, arts, science and integrated activities.

To investigate parental involvement sections of activity plans, a control list had been designed. The control list gathered 18 items initially. One of the items were dropped after the specialists' proposals. Parental Involvement Activity List was consisted of 17 items with a three type Likert scale. This control list was used to analyze parental involvement sections of activity plans. Results were presented in frequencies and percentages.

\section{FINDINGS}

349 activity had been collected and results show that only 119 of them (\%32) included parental involvement section. It can be suggested that \%32 percent is not enough to establish a good parental involvement process. All activities found to be applicable and has some degree of valuable interaction. On the other hand it has been seen that there were some missing dimensions in all activities that fit the nature of the activity. Besides, all activities were found to be poor in terms of outside of home activities (\%87), neighborhood opportunities (\%61), asking for waste materials (\%93), particular goods (\%62), having particular goods in classroom (\%87), having help for school routines (\%100), having help for teacher work (\%97) and having parents in classroom activities (\%94).

Considering children's developmental areas, it has been found that language development of children (\%95), social-emotional development (\%78), and psychomotor development (\% 91) were not supported adequately. Results showed that regardless of activity type, parental involvement activities were planned to support cognitive development $(\% 75)$.

\section{RESULTS AND DISCUSSION}

This study aimed to gather some preliminary information on parental involvement sections of activity plans. Studies focused on early childhood era show that parent centered education is common. Researchers are especially interested in early learning experiences of children and interaction strategies among parent, child and school (Temel, 2001 and Connely, 2007). However this study indicated that parental involvement in activity plans had poor involvement strategies. It has been suggested that having variety of parental involvement strategies effect the quality of involvement process. This brings a better result for 
Cumhuriyet International Journal of Education-CIJE

e-ISSN: $2147-1606$

Vol 5 (1), 2016, $71-84$

developments and learning achievements of the children. Study indicated that not only quality of the parental involvement in activity plans should be supported, but also quantity of them. 